\title{
Plants in constructed wetlands help to treat agricultural processing wastewater
}

by Mark E. Grismer and Heather L. Shepherd

Over the past three decades, wineries in the western United States and sugarcane processing for ethanol in Central and South America have experienced problems related to the treatment and disposal of process wastewater. Both winery and sugarcane (molasses) wastewaters are characterized by large organic loadings that change seasonally and are detrimental to aquatic life. We examined the role of plants for treating these wastewaters in constructed wetlands. In the greenhouse, subsurface-flow flumes with volcanic rock substrates and plants steadily removed approximately $80 \%$ of organic-loading oxygen demand from sugarcane process wastewater after about 3 weeks of plant growth; unplanted flumes removed about $30 \%$ less. In field studies at two operational wineries, we evaluated the performance of similar-sized, paired, subsurface constructed wetlands with and without plants; while both removed most of the oxygen demand, removal rates in the planted system were slightly greater and significantly different from those of the unplanted system under field conditions.

The processing of sugarcane to cre-
ate molasses for ethanol fuel and feedstock is rapidly expanding across Central and South America, while the number of vineyards and wineries continues to increase across the western United States. Both industries generate process wastewater (PWW) of variable quality, which can have deleterious impacts on receiving surface waters when discharged downstream.

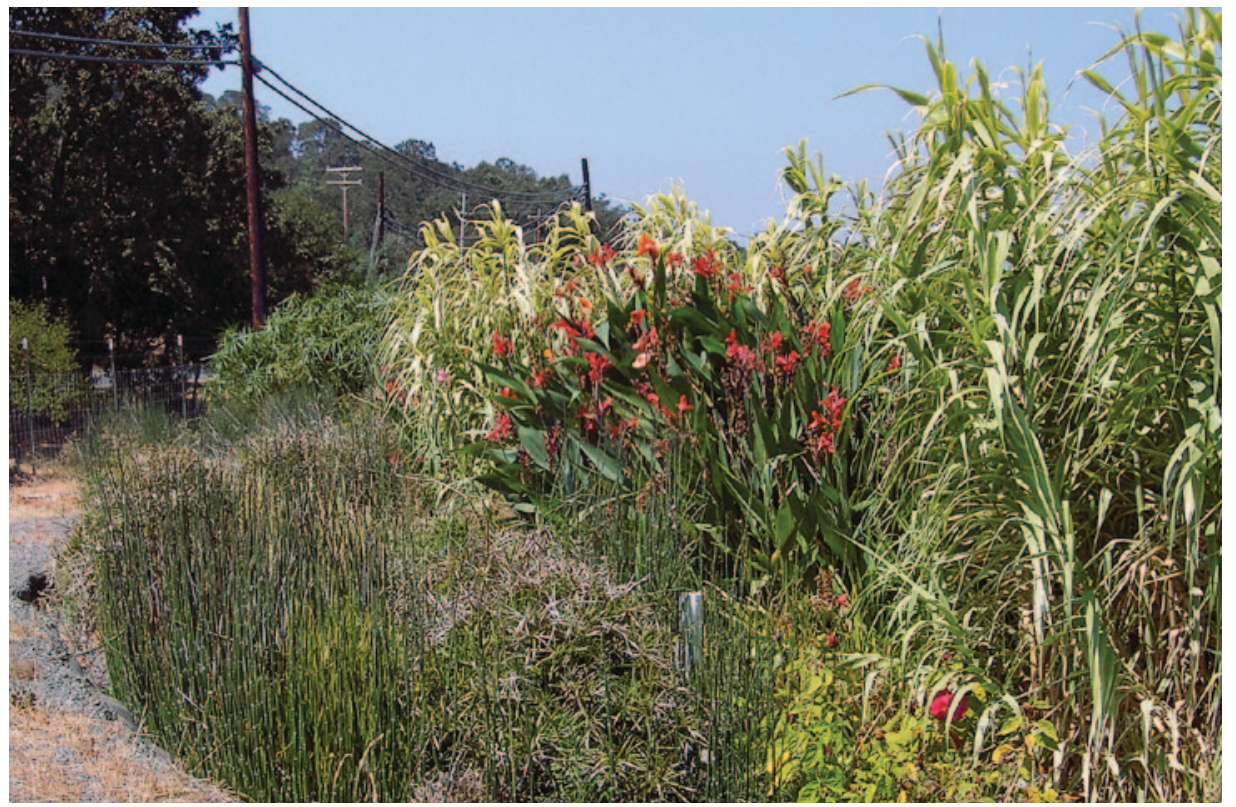

Agricultural processing wastewaters may have high concentrations of organic matter that contaminate surface waters when discharged downstream. At Imagery Estate Winery in Glen Ellen, constructed wetlands with plants were tested for their ability to remove pollutants.

Shepherd et al. (2001) described the negative impacts of winery wastewater downstream, which led to requirements for its control and on-site treatment. Similarly, downstream degradation from sugarcane process waters has been documented in the Ipojuca River of northeast Brazil (Gunkel et al. 2006) and in coastal lagoons of northwest Mexico (González-Farias et al. 2006). Wastewater from molasses processing follows a seasonal variation similar to that of wineries, with high flows and loadings from November through May, followed by harvesting and grape crush in late summer and early fall.

Both winery and molasses process wastewaters are responsive to natural treatment strategies prior to discharge. Remnant wetland systems, relatively common in the drainage channels of Central and South America, may be employed. Likewise, constructed wetlands have been designed and installed to treat winery process wastewater in California. Surprisingly, the role of plants and their associated biofilms in such systems is poorly understood and not well documented relative to treatment performance.

\section{Sugarcane and winery wastewater}

Sugarcane, food-processing, winery and other distilleries generate wastewaters from processing and equipment wash-down. These differ greatly from domestic wastewater because of their high organic-matter concentrations, variable flow rates, relatively low levels of nutrients, low $\mathrm{pH}$ and lack of pathogens. Gunkel et al. (2006) monitored sugarcane fertigation and wash-down waters (used to clean equipment) in Brazil and noted their very low $\mathrm{pH}$ (3.8) and high sodium (1,320 milligrams per liter), salinity and organic loads. Kumar et al. (2007) obtained similar results in India and also noted high sulfates.

To determine the characteristics of sugarcane process wastewater in Mexico, in March 2007 we compared wastewater from a typical processor, Ingenio La Gloria, located on the coast south of Veracruz (Olguín et al. 2008), to sugarcane process wastewater in India and Brazil, and process wastewater from a California winery (table 1). In Mexico, sugarcane process wastewater is typically diluted 10 to 100 times with canal water prior to reuse for irrigation or release into drainage channels, 
making it similar in quality to that reported for Brazil. The biological oxygen demand $\left(\mathrm{BOD}_{5}, 5\right.$-day holding time) and chemical oxygen demand (COD) concentrations (both measures of organic loading), and $\mathrm{BOD}_{5}$-to-COD ratio, for Brazilian sugarcane wastewater as diluted for fertigation - were nearly the same as that for the California winery process wastewater. While at much higher concentrations, the $\mathrm{BOD}_{5^{-}}$ to-COD ratio for the Indian sugarcane process wastewater was similar.

Shepherd et al. (2001) proposed that constructed wetlands are an attractive treatment system for moderate-sized wineries, with their ability to assimilate variable and large organic loadings as well as their low maintenance and operational costs. Likewise, process wastewaters can be treated naturally in drainage channels constructed at the outflow of sugarcane processing factories. Such constructed wetlands make use of wetland plants and associated microorganisms on the roots (called biofilms) to degrade organic pollutants such as carbohydrates, proteins and other carbon-based suspended matter that comprise the wastewater's $\mathrm{BOD}_{5}$ and COD load.

Free-water surface ponds are one type of constructed wetland. In this system, vegetation is planted in base soils below water as deep as 4 feet. These systems are easy to maintain and are acceptable for relatively modest organic loadings, but generally they are not appropriate for winery or sugarcane processing unless the wastewater is pretreated (such as in aerated ponds, for odor and mosquito control).

Another type of constructed wetland, called subsurface-flow or vegetated submerged beds (fig. 1), involves planting wetland vegetation directly into a gravel substrate 3 to 4 feet deep. The wastewater passes through the gravel but does not cover its surface. This system has greater treatment capability but also higher initial installation costs.

Rates of flow into such constructed wetlands are managed so that there is sufficient hydraulic residence time (HRT) for adequate treatment. COD or $\mathrm{BOD}_{5}$ removal rates are typically modeled as first-order degradation (decay) processes (Shepherd et al. 2001).

TABLE 1. Comparison of process wastewaters (PWW) from sugarcane in Mexico (Ingenio La Gloria, Veracruz), Brazil and India; and a California winery

\begin{tabular}{|c|c|c|c|c|c|c|}
\hline \multirow[b]{2}{*}{ Parameter* } & \multirow{2}{*}{$\begin{array}{c}\text { Winery } \\
\text { Calif. PWW* }\end{array}$} & \multicolumn{4}{|c|}{ Sugarcane (molasses) } & \multirow[b]{2}{*}{$( \pm S D)$} \\
\hline & & $\begin{array}{c}\text { Brazil } \\
\text { fertigationt }\end{array}$ & $\begin{array}{c}\text { Brazil } \\
\text { wash-downt }\end{array}$ & $\begin{array}{l}\text { India } \\
\text { PWW }\end{array}$ & $\begin{array}{l}\text { Mexico } \\
\text { PWW }\end{array}$ & \\
\hline & $\ldots \ldots \ldots \ldots$ & $\ldots \ldots \ldots \ldots$ & $\cdots m g / L \cdots \cdots$ & $\ldots \ldots \ldots$ & $\ldots \ldots \ldots$ & \\
\hline $\begin{array}{l}\text { Chemical oxygen } \\
\text { demand (COD) }\end{array}$ & 22,290 & 23,727 & 1,050 & 105,000 & 118,270 & 305 \\
\hline $\begin{array}{l}\text { Biological oxygen } \\
\text { demand }\left(\mathrm{BOD}_{5}\right)\end{array}$ & 14,490 & 10,800 & 388 & 52,500 & 52,200 & 200 \\
\hline $\begin{array}{l}\text { Total Kjendahl } \\
\text { nitrogen (TKN) }\end{array}$ & & & & & 1,598 & 106 \\
\hline $\begin{array}{l}\text { Nitrogen as ammonia } \\
\left(\mathrm{N}-\mathrm{NH}_{3}\right)\end{array}$ & & & & & 772 & 16 \\
\hline $\begin{array}{l}\text { Nitrogen as nitrate } \\
\left(\mathrm{N}-\mathrm{NO}_{3}\right)\end{array}$ & 163 & & & & 312 & 10 \\
\hline $\begin{array}{l}\text { Phosphorus as } \\
\text { phosphate }\left(\mathrm{P}-\mathrm{PO}_{4}\right)\end{array}$ & & $\begin{array}{r}67.7 \\
\text { (total) }\end{array}$ & $\begin{array}{r}2.2 \\
\text { (total) }\end{array}$ & & 1,100 & 45 \\
\hline $\begin{array}{l}\text { Sulfur as sulfate } \\
\left(\mathrm{S}-\mathrm{SO}_{4}\right)\end{array}$ & 61 & & & 6,250 & 8,220 & 197 \\
\hline Potassium (K) & & & & & 19,250 & 250 \\
\hline Total solids (TS) & $\begin{array}{r}1,120 \\
\text { (TSS) } \\
\end{array}$ & & & 85,000 & 106,465 & 1,534 \\
\hline $\begin{array}{l}\text { * Source: Shepherd, Grisme } \\
\text { † Source: Gunkel et al. } 2006 \\
\text { ‡ Source: Kumar et al. } 2007\end{array}$ & er et al. 2001. & & & & & \\
\hline
\end{tabular}

While plants are understood to be important to treating process wastewater in constructed wetlands, little quantitative information is available. Biofilms are defined as spatially and metabolically structured microbial communities (Nikolaev and Plakunov 2007) that interact with plant roots and the soil-water environment, while constantly adapting to changes in both. As such, plant roots provide the structure needed for biofilm bacteria to process wastewater. Biofilm microorganisms consume organic material and ultimately release carbon dioxide and water, or methane and water, depending on the amount of oxygen present. Since the surface area of plant roots is far greater than that of the sand/gravel/ rock substrate alone, and because roots have the ability to partially oxygenate their surfaces, they can support thicker and perhaps more robust biofilms. In addition, plants consume some of the process wastewater nutrients, while roots physically filter them. In some cases the aesthetic appearance of the constructed wetland is not a concern, but the processing plant operators may not see the benefit of maintaining vegetation in planted wetlands. Our investigation was directed at determining the relative value of planted versus unplanted systems.

\section{Constructed-wetland performance}

The success of constructed wetlands in treating process wastewaters containing high-strength organic matter depends on several factors related primarily to organic loading, HRTs, the tolerance of selected plants to possibly toxic components in the process wastewater, and plant biofilm activity. Comprehensive research reviews of brewery, winery and related distillery treatment methods for process wastewater have underscored the need for additional research, particularly of fullscale systems and individual processes (Grismer and Shepherd 1998; Grismer et al. 1999, 2000, 2002, 2003). Shepherd, Grismer et al. (2001) evaluated the performance of a subsurface-flow wetland (20 feet long, 8 feet wide and 4 feet deep) in treating winery process wastewater flows ranging from 80 to 170 cubic meters per day at organic loads of 600 to 45,000 milligrams COD per liter (mg COD/l), and measured average removal rates of $98 \%$ for COD and $97 \%$ for total suspended solids (TSS) when combining the constructed wetland with an upflow sand prefilter. The system also 
effectively neutralized the $\mathrm{pH}$ of the acidic winery wastewater and removed the limited nitrogen (78.2\%), sulfide (98.5\%), orthophosphate $(63.3 \%)$, volatile fatty acids (99.9\%), tannins and lignins $(77.9 \%)$ and all settleable solids.

Olguín et al. (2008) achieved similar results from greenhouse-based, fiberglass, subsurface "flumes" (long, narrow boxes 10 feet long, 1 foot wide and 1.6 feet deep), used to treat diluted molasses process wastewater with 2.5- or 5-day HRTs and an average inlet concentration of 1,184 $\mathrm{mg}$ COD/1 (534 mg BOD $5 / 1$ ). After 30 to 40 days of plant (Pistia sagittata) establishment, the planted flumes achieved average removal rates of $80.2 \%$ for COD, $87.3 \%$ for $\mathrm{BOD}_{5}, 76.1 \%$ for total Kjeldahl nitrogen (TKN, the sum of organic nitrogen, ammonia and ammonium) and $68.6 \%$ for sulfate during the next month. In the same period, the corresponding control nonplanted flume achieved removal rates significantly lower than that of the planted flume - $40.1 \%$ for COD, $60.9 \%$ for $\mathrm{BOD}_{5}, 55.5 \%$ for $\mathrm{TKN}$ and $57.0 \%$ for sulfate.

Evaluating constructed wetlands in the field requires not only analysis of constituent degradation, or transformation, but also a hydraulic assessment of its bed-flow properties under the variable operating conditions of actual use (Grismer 2005). In the only published field-scale evaluation, Grismer et al. (2003) - using tracer methods developed by Grismer et al. (2001) - measured constructed-wetland degradation constants, HRTs and treatment performance at two operating

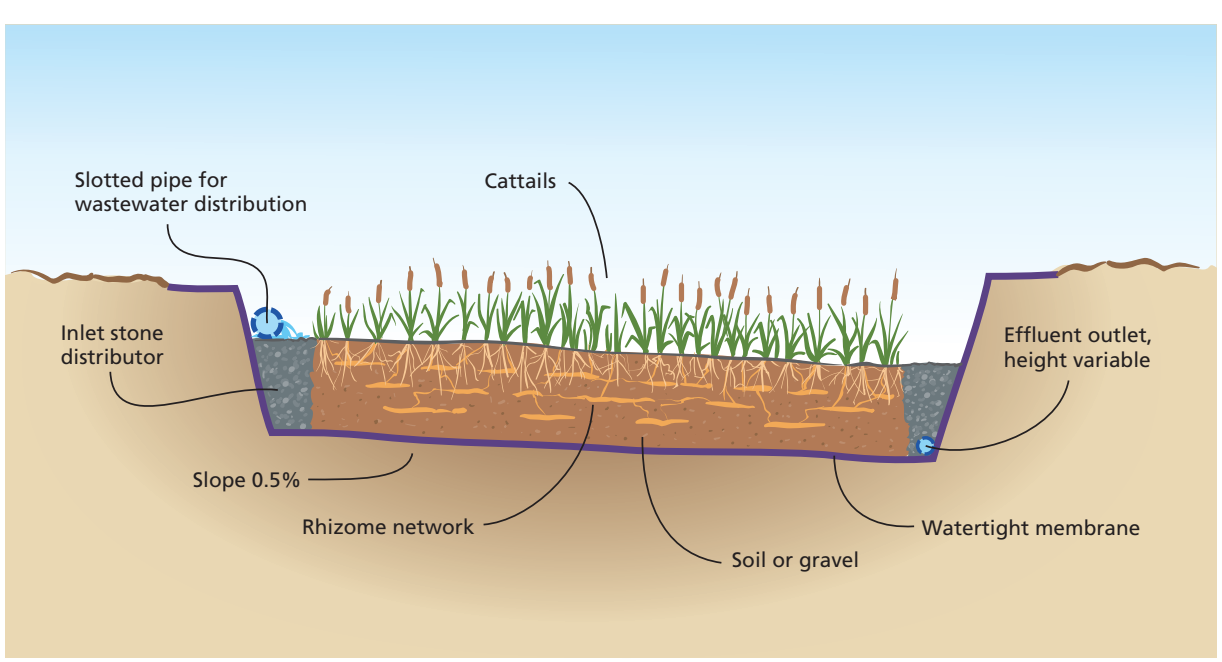

Fig. 1. Cross-section of subsurface-flow constructed wetland.

wineries. System performance was evaluated through daily sampling of total dissolved solids (TDS), $\mathrm{pH}$, total suspended solids, COD, tannins, nitrate, ammonium, TKN, phosphate, sulfate and sulfide.

The larger winery system showed similar COD and tannin removal rates to those of bench-scale columns (constructed of PVC pipes 6 inches in diameter by 24 inches tall), ranging from $49 \%$ to $79 \%$ (columns) and $46 \%$ to $78 \%$ (constructed wetlands). Greater removal occurred during the spring, noncrush period. During the crush season, with HRTs of about an hour compared to about 5 days during the noncrush season, the constructed wetland reduced inlet COD by half and other constituents $20 \%$ to $30 \%$. Though it had smaller loading rates and greater HRTs, the small winery's constructed-wetland system achieved nearly complete COD removal (from about 8,000 to $5 \mathrm{mg} / \mathrm{l}$ ) through the use of a recirculation system. These results suggested that the wetland system was quite capable of fully treating winery process wastewater when properly loaded and operated. Understanding the HRTs through tracer study analyses was crucial to the interpretation of water-quality measurements from the wetland.

While there is some literature on bench and pilot-scale testing for loadings and HRTs, scant information is available related to plant and biofilm factors, especially at the field scale. Constructed-wetland systems had not been compared side-by-side, with and without plants, for the high-strength process wastewaters typical of wineries and sugarcane processing. Moreover, the selection of suitable plants for treating process wastewaters depends in part on plants found locally, but little detailed information has been available to help guide that selection.

We conducted complementary green house (Mexico) and field (California) studies for treating molasses and winery process wastewater in constructed wetlands, with and without plants. In the greenhouse studies, we also considered the rate of plant growth and its effect on process wastewater (Olguín et al. 2008). In California, where plants are normally allowed to establish for about a year prior to the introduction of process wastewater, we monitored two planted and unplanted pairs of constructed wetlands at wineries on the Central Coast. In both cases, the wineries anticipated future expansion and chose to build two subsurface systems, one for current operations and another for the expansion. Since the second constructed wetland would not be in use for several years, it was installed without plants, allowing us to monitor and evaluate treatment performance under operating conditions.

\section{Greenhouse and field studies}

Mexico greenhouse studies. At the Instituto de Ecología near Xalapa, Mexico, we employed the greenhouse facilities, constructed-wetland flumes and methods, all as described by Olguín et al. (2008). Duplicate flumes were used for each of the three different treatment systems and HRTs. These systems included a surface treatment with aquatic plants, a subsurface-flow treatment with plants, and a subsurface-flow treatment without plants (control). Two HRTs (2.5 and 5 days) were used for the planted systems, while only the 2.5-day time was used in the control. There were 10 flumes in total.

Different HRTs were used to develop preliminary estimates of the degradation constants necessary for field designs of constructed wetlands. Substrate in the subsurface flumes consisted of volcanic rock approximately 1.5 inches (40 millimeters) across, with a net porosity of about $50 \%$, resulting in a flume volume of approximately 45 gallons (170 liters). In the surface treatment, we used 

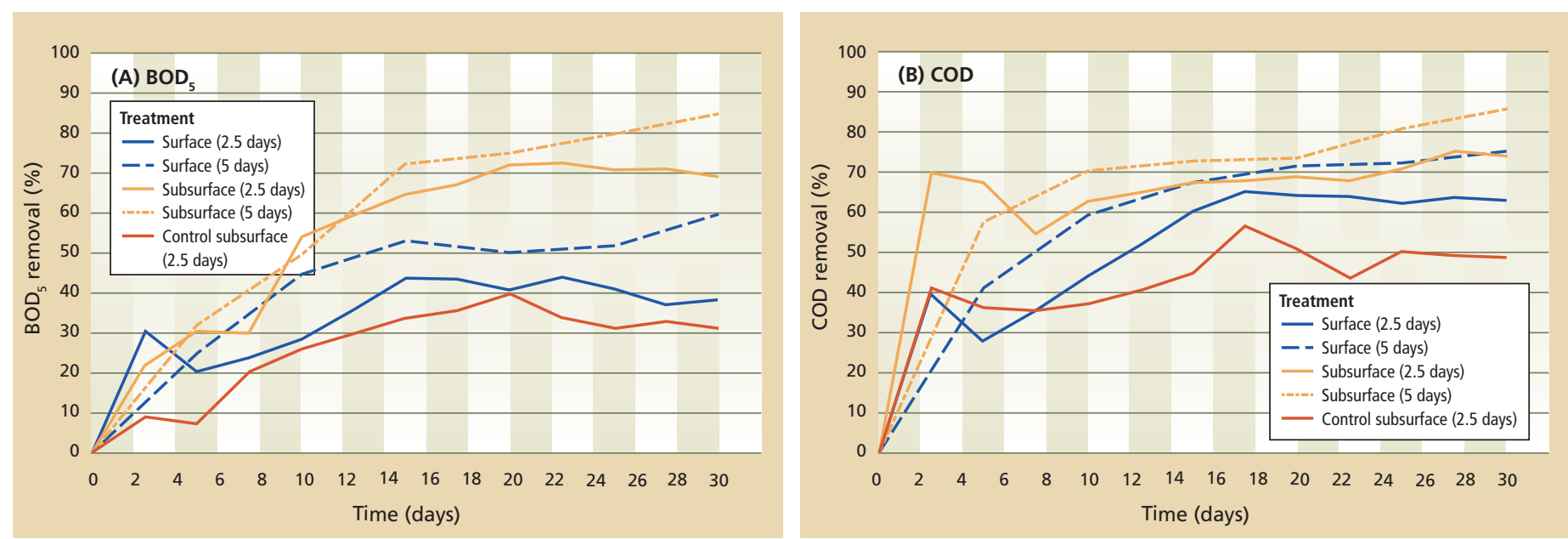

Fig. 2. Daily variation of removal efficiencies for $(A)$ biological oxygen demand, 5 days $\left(B O D_{5}\right)$ and $(B)$ chemical oxygen demand $(C O D)$ in constructed-wetland greenhouse flume experiments.

the aquatic plant water lettuce (Pistia stratiotes), while the subsurface treatment was planted with pickerelweed (Pontederia cordata). Plants were allowed 3 weeks to establish and acclimate in local canal water before the experiments were initiated with 100-to-1 diluted sugarcane process wastewater.

Flow rates were carefully maintained, with steady flow provided by Masterflex peristaltic pumps for 30 days of monitoring at the inlet and outlet of each flume. In this study we focused on $\mathrm{BOD}_{5} / \mathrm{COD}$ removal, based on sampling at 2.5- and 5-day intervals corresponding to flume HRTs. Relatively constant ambient conditions were maintained during May 2006. The overall mean temperature was $79.7^{\circ} \mathrm{F}\left(26.5^{\circ} \mathrm{C}\right)$, while the average evapotranspiration rate was 0.26 inches (6.7 millimeters) per day.

California field studies. Field studies were conducted on the California Central Coast at two wineries (A and B) to evaluate treatment effects on similarly sized, paired (planted/unplanted), subsurface constructed wetlands. At winery A, the systems were sized to handle process wastewater from the production of 14,000 cases of wine, with each wetland designed to treat half this process wastewater (that from about 7,000 cases of production). Each paired wetland was 52 feet by 12 feet by 3 feet deep, with washed pea gravel roughly 0.3 inches ( $<8$ millimeters) in diameter.

Subsurface wetlands at winery B were also sized to treat process wastewater from 14,000 cases of wine, but the expansion phases were different. One of the wetlands was designed to treat the process wastewater from 8,000 cases and the other from 6,000 cases; they were 55 feet by 14 feet, and 44 feet by 12 feet, respectively, both with approximately 3-foot-deep washed pea gravel.

At both sites, one of the wetlands had been planted with cattails (Typha dominigensis), bulrushes (Scirpus acutus) and some arrowheads (Sagittaria latifolia) the June previous to monitoring. These wetland plants were established though not fully grown by October. In both wineries, the process wastewater was pretreated in septic tanks designed to have a 2-day retention time. Also, both treatments were designed to have 10-day HRTs, though as noted above, in previous field studies the actual field times differed. Winery process wastewater flows were evenly split into the planted and unplanted treatments at the two wineries.

For 2 weeks during the October 2006 harvest, daily water samples were taken from the inlets and outlets of each constructed wetland (planted and unplanted at each winery) with care taken to sample at roughly the same time each day, when wastewater was flowing. Samples for $\mathrm{COD}, \mathrm{BOD}_{5}$ and total suspended solids were refrigerated and analyzed daily in the lab, while $\mathrm{pH}$ and total dissolved solids were measured directly in the field. As in Mexico, samples were generally analyzed immediately after collection following standard methods using Hach tests accepted by the U.S. Environmental Protection
Agency. COD was measured using the closed-reflux colorimetric method adapted from Standard Methods 5220 D. The lower detection limit of the COD analysis was $1 \mathrm{mg}$ COD/l. Total suspended solids were measured using the Hach 2010 Spectrophotometer turbidimetric method. In the field, $\mathrm{pH}$ was measured immediately after sampling using the Hach EC10 portable $\mathrm{pH}$ meter calibrated against $\mathrm{pH} 4$ and $\mathrm{pH} 7$ standards. Total dissolved solids were measured using the Hach Conductivity/ TDS meter. Measured daily plug-flow rates were used to determine the actual HRTs of process wastewater in each constructed wetland following methods described by Grismer et al. (2001, 2003).

Statistical analysis. Because these studies only involved comparisons of mean outlet concentrations from the different treatments, we used simple single-tailed confidence level tests to determine the relative significance of differences in concentrations after they stabilized, or after 15 days in the greenhouse flumes.

\section{Greenhouse flume measurements}

System performance. $\mathrm{BOD}_{5}$ (fig. $2 \mathrm{~A}$ ) and COD (fig. 2B) removal rates steadily improved during the first 15 days of the greenhouse tests, after which they stabilized, presumably in response to additional plant growth and acclimation to the process wastewater (table 2). Average $\mathrm{BOD}_{5}$-removal rates after 15 days were $34 \%$ for the unplanted control, $41 \%$ and $53 \%$ for the surface system, followed by $70 \%$ and $78 \%$ for 
the subsurface system, with HRTs of 2.5 and 5 days in both treatments, respectively. All mean outlet $\mathrm{BOD}_{5}$ concentrations differed at greater than $99.9 \%$ confidence levels $(P<0.00005)$.

Similarly, mean COD-removal rates after 15 days of sampling were $49 \%$ for the control, $63 \%$ and $71 \%$ for the surface system, followed by $70 \%$ and $78 \%$ for the subsurface system, again at HRTs of 2.5 and 5 days, respectively. With the exception of the means comparison between outlet COD concentrations from the subsurface ( 2.5 days) and the surface (5 days) treatments having a significant difference at the approximately $96 \%$ confidence level, all remaining mean outlet COD concentrations differed at greater than $99.9 \%$ confidence levels ( $P$ $<0.00005)$.

The greenhouse studies showed that (1) the subsurface treatment outperformed the surface treatment in terms of $\mathrm{BOD}_{5}$ and $\mathrm{COD}$ removal at both HRTs; (2) not surprisingly, greater HRTs resulted in greater removal rates of $\mathrm{BOD}_{5}$ and $\mathrm{COD}$ for both systems; and (3) the planted subsurface system significantly outperformed the unplanted control in terms of $\mathrm{BOD}_{5}$ and $\mathrm{COD}$ removal.

BOD $_{5}$ and COD degradation. The use of two different HRTs in the greenhouse studies enabled preliminary assessment of the simple first-order degradation constants (K) for each system, and how they varied with time during the 30-day test period. Such information is useful for the field designs of constructed-wetland systems. In addition, because COD is a measure of all possible oxygen-consuming material in the process wastewater, changes in $\mathrm{BOD}_{5}$-to-COD ratio during the experimental period provide an indication of the relative ability of each system to degrade progressively more-recalcitrant organic compounds in the process wastewater (fig. 3). The K values for COD increased and appeared to stabilize after about 2 weeks. In this study, we found stable degradation constants of 0.2 and 0.4 per day for the surface and subsurface systems, respectively; this is much lower than the constant of about 1.5 per day found by Shepherd, Tchobanoglous et al. (2001) in pilot-scale, subsurface treatment of winery process wastewater in Davis used as the basis for our field experiment design. Our smaller K values may be due to the larger volcanic rock substrate used in the flumes as compared to the pea gravel used by Shepherd, Tchobanoglous et al. (2001).

Perhaps more interesting is the change in average $\mathrm{BOD}_{5}$-to-COD ratios from those of the initial wastewater stream $\left(\mathrm{BOD}_{5}\right.$-to-COD $\left.=0.44\right)$. In the subsurface treatment, the ratio dramatically increased to greater than 1.0, leveling off to about 0.5 after 2 weeks. Meanwhile, this ratio remained approximately unchanged in the control at 0.55 to 0.60 , and steadily increased to roughly 0.75 in the surface treatment. The latter ratio reflects the greater treatment capability of the combined plant/ gravel biofilm system after acclimation

TABLE 2. Mean outlet chemical (COD) and biological $\left(B O D_{5}\right)$ oxygen demand concentrations from greenhouse flumes after 15 days of flow through constructed wetlands

\begin{tabular}{|c|c|c|c|c|c|c|}
\hline \multirow[b]{2}{*}{ Treatment (HRT*) } & \multicolumn{3}{|c|}{ BOD $_{5}$} & \multicolumn{3}{|c|}{ COD } \\
\hline & Inlet & Outlet & Outlet SDt & Inlet & Outlet & Outlet SD \\
\hline & \multicolumn{3}{|c|}{$\cdots \cdots \cdots m g / L(n) \cdots \cdots \cdots$} & \multicolumn{3}{|c|}{$\cdots \cdots \cdots m g / L(n) \cdots \cdots \cdots$} \\
\hline Control (subsurface) & $522(14)$ & 344 & 16.7 & $1,183(28)$ & 605 & 49.5 \\
\hline Surface (2.5 hours) & $522(14)$ & 307 & 14.1 & $1,183(28)$ & 437 & 21.0 \\
\hline Surface (5 hours) & $522(8)$ & 242 & 23.0 & $1,183(16)$ & 338 & 34.5 \\
\hline Subsurface ( 2.5 hours) & $522(14)$ & 159 & 16.2 & $1,183(28)$ & 359 & 42.9 \\
\hline Subsurface (5 hours) & $522(8)$ & 116 & 27.3 & $1,183(16)$ & 260 & 60.4 \\
\hline
\end{tabular}

in the subsurface system compared to that of the surface system.

In the subsurface system, 3 to 4 weeks were sufficient for plant establishment to achieve the steady removal rates reported by Olguín et al. (2008). Overall, COD removal rates indicate that the use of constructed-wetland systems in the drainage canals leaving sugarcane processing facilities should be advantageous for improving downstream water quality.

\section{Winery subsurface-flow systems}

Winery A. Under actual field operations, the performance of constructedwetland systems in California was variable depending on the winery process wastewater flows and loading rates. Due to greater wine production than anticipated at winery A, inlet loading (flow and COD concentrations) was much greater and more variable than anticipated, resulting in daily HRTs of roughly half the design value of 10 days, although constant. After 5 days of sampling at winery A, inlet COD loading peaked from roughly $60,000 \mathrm{mg} / 1$ to more than $130,000 \mathrm{mg} / \mathrm{l}$ for about 2 days due to uncollected juice flowing into the treatment system. This situation was corrected, and inlet COD concentrations steadily decreased to about $60,000 \mathrm{mg} / \mathrm{l}$ by day 11 of sampling. Outlet COD concentrations ranged from approximately 600 to $5,200 \mathrm{mg} / 1$ from the planted treatment to 600 to 8,800 $\mathrm{mg} / \mathrm{l}$ from the unplanted treatment at winery A. Inlet total-suspended-solids 


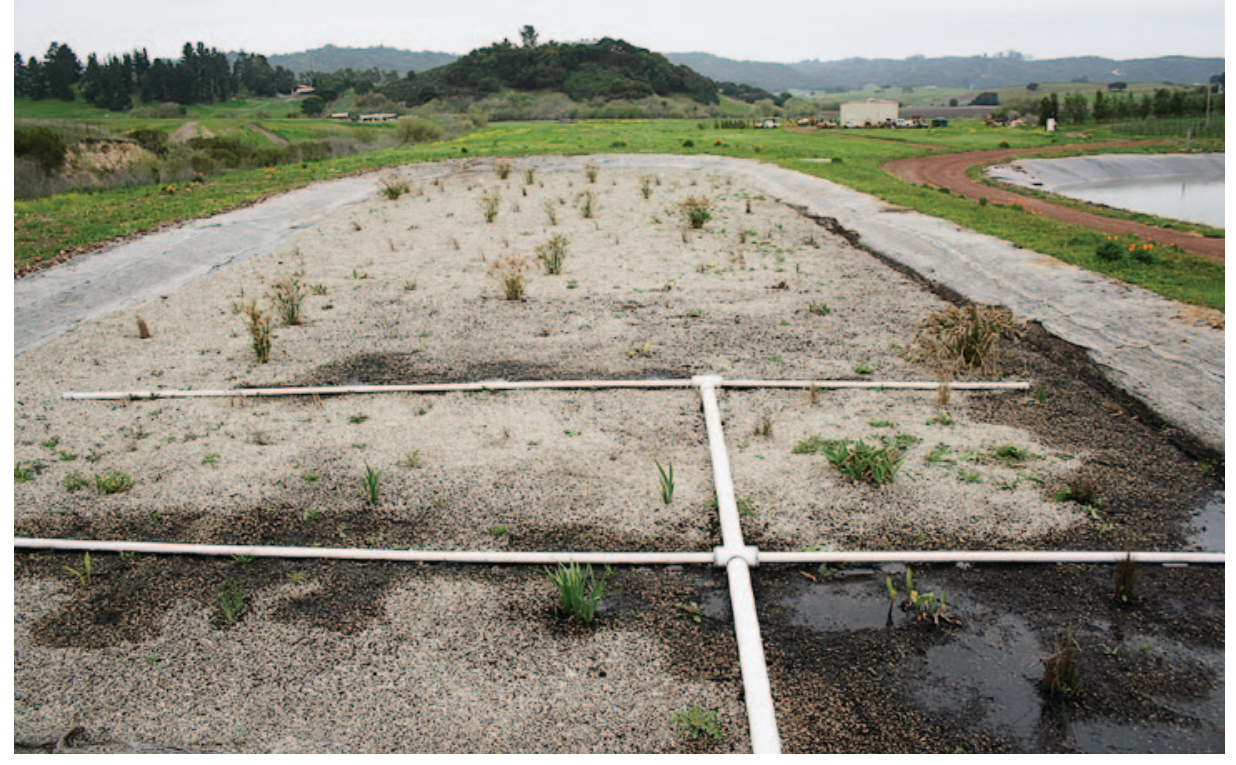

Piping disperses process wastewater across the width of a constructed wetland at a Paso Robles winery. Samples were taken at the outflow (not shown) and the far end of the wetland, which was designed to handle wastewater generated by producing 14,000 cases of wine.

concentrations ranged from 160 to 450 $\mathrm{mg} / \mathrm{l}$, and corresponding outlet concentrations ranged from 20 to $160 \mathrm{mg} / \mathrm{l}$ and 50 to $260 \mathrm{mg} / \mathrm{l}$ from the planted and unplanted wetlands, respectively.

Winery B. Conversely, at winery B full wine production was not achieved, and daily flow rates and loadings were much smaller and less variable. As a result, there were different flow rates to each constructed wetland and much greater HRTs, about double the design value of 10 days. Flow and loading conditions at winery $\mathrm{B}$ were more typical; inlet COD values were as high as 7,000 $\mathrm{mg} / \mathrm{l}$ and outlet values ranged from 14 to $48 \mathrm{mg} / \mathrm{l}$ and 68 to $138 \mathrm{mg} / \mathrm{l}$ for the planted and unplanted treatments, respectively. Average total-suspendedsolids concentrations at the winery $\mathrm{B}$ inlet were similar to those at winery A, ranging from 240 to $420 \mathrm{mg} / \mathrm{l}$, but corresponding concentrations at the outlet were far less, ranging from 18 to $34 \mathrm{mg} / \mathrm{l}$ and 26 to $64 \mathrm{mg} / \mathrm{l}$ for the planted and unplanted wetlands, respectively. The average removal rates for total suspended solids of $76 \%$ (53\% for unplanted) as compared to $91 \%(85 \%$ for unplanted) reflect the much shorter HRTs encountered at winery A compared to winery B.

Plants and treatment performance. Because COD and total-suspendedsolids concentrations at the inlet of winery A were roughly 10 times greater than those at winery B - and as a result, HRTs were only one-third that for winery $B$ - concentrations at the outlet were also considerably greater at winery A (table 3). This fortuitous change enabled us to better evaluate the effects of plants on treatment performance across a greater range of loading conditions than originally planned.

The mean outlet concentrations of COD, total suspended solids, total dissolved solids and $\mathrm{pH}$ between the planted and unplanted wetlands at winery A all differed significantly at greater than $99 \%$ confidence levels. Similarly, at winery B, despite significantly greater HRTs in the unplanted treatment, mean outlet concentrations between the planted and unplanted treatments were also significantly different at greater than $99 \%$ confidence levels. Outlet concentrations differed at the $95 \%$ confidence level.

At both wineries, salinity and total-dissolved-solids concentrations increased as a result of evapoconcentration within the constructed wetland. The subsurface treatments at both wineries were successful in substantially reducing COD and total suspended solids at the outlet by more than $96 \%$ and $76 \%$, respectively, with the planted system significantly outperforming the unplanted system. Finally, acidic $\mathrm{pH}$ of the process wastewater at both winery inlets was more successfully neutralized by the planted than the unplanted wetlands.

Overall, the field evaluation demonstrated that plants can play a significant role in treating process wastewater from wineries. While the planted

TABLE 3. Field inlet/outlet monitoring (14 days) of subsurface-flow constructed wetlands for process wastewater treatment at two California wineries

\begin{tabular}{|c|c|c|c|c|c|c|c|c|c|c|c|c|c|c|}
\hline \multirow[b]{2}{*}{ Parameter } & \multicolumn{2}{|c|}{ HRT* } & \multicolumn{3}{|c|}{ COD } & \multicolumn{3}{|c|}{ TSS } & \multicolumn{3}{|c|}{ TDS } & \multicolumn{3}{|c|}{$\mathrm{pH}$} \\
\hline & $\begin{array}{c}\text { Planted } \\
\text { outlet }\end{array}$ & $\begin{array}{c}\text { Unplanted } \\
\text { outlet }\end{array}$ & Inlet & $\begin{array}{l}\text { Planted } \\
\text { outlet }\end{array}$ & $\begin{array}{c}\text { Unplanted } \\
\text { outlet }\end{array}$ & Inlet & $\begin{array}{c}\text { Planted } \\
\text { outlet }\end{array}$ & $\begin{array}{c}\text { Unplanted } \\
\text { outlet }\end{array}$ & Inlet & $\begin{array}{c}\text { Planted } \\
\text { outlet }\end{array}$ & $\begin{array}{c}\text { Unplanted } \\
\text { outlet }\end{array}$ & Inlet & $\begin{array}{l}\text { Planted } \\
\text { outlet }\end{array}$ & $\begin{array}{c}\text { Unplanted } \\
\text { outlet }\end{array}$ \\
\hline & \multicolumn{2}{|c|}{$\cdots \cdots$ days $\cdots \cdots$} & $\cdots \cdots$ & $\cdots \cdots \cdots$ & $\cdots \cdots$ & $\cdots \cdots$ & $\cdots m g / L$ & $\cdots \cdots \cdots$ & $\cdots \cdots$ & $\cdots \cdots \cdots$ & $\cdots \cdots \cdots$ & & & \\
\hline \multicolumn{15}{|l|}{ Winery A } \\
\hline Mean & 6.0 & 6.0 & 72,965 & 2,321 & 4,770 & 297.9 & 71.3 & 140.5 & 639 & 1,447 & 1,910 & 4.50 & 6.41 & 5.81 \\
\hline $\begin{array}{l}\text { Standard } \\
\text { deviation }\end{array}$ & 1.6 & 1.6 & 29,066 & 1,512 & 2,649 & 95.0 & 44.6 & 59.2 & 33 & 366 & 321 & 0.28 & 0.33 & 0.33 \\
\hline$P$ value/CL $†$ & & & & 0.0013 & $>99 \%$ & & 0.0002 & $>99 \%$ & & 0.0002 & $>99 \%$ & & $<0.0001$ & $>99 \%$ \\
\hline Average ren & noval (\%) & & & 96.8 & 93.5 & & 76.1 & 52.8 & & & & & & \\
\hline \multicolumn{15}{|c|}{ Winery B } \\
\hline Mean & 17.5 & 24.1 & 5,080 & 30.8 & 106.0 & 324 & 27.5 & 44.50 & 615 & 1,178 & 1,401 & 5.35 & 6.96 & 6.52 \\
\hline $\begin{array}{l}\text { Standard } \\
\text { deviation }\end{array}$ & 4.6 & 6.3 & 1,211 & 9.2 & 23.3 & 54.6 & 6.10 & 10.02 & 28.7 & 168 & 244 & 0.56 & 0.17 & 0.17 \\
\hline$P$ value/CL & 0.0008 & $>99 \%$ & & 0.0465 & $>95 \%$ & & $<0.0001$ & $>99 \%$ & & $<0.0024$ & > 99\% & & $<0.0001$ & $>99 \%$ \\
\hline \multicolumn{3}{|c|}{ Average removal (\%) } & & 99.3 & 97.9 & & 91.1 & 85.5 & & & & & & \\
\hline
\end{tabular}


constructed wetlands were less than 1 year old and not fully developed, they showed consistently better removal of COD and total suspended solids, as well as better $\mathrm{pH}$ neutralization.

\section{Understanding natural treatments}

Natural wastewater treatment systems have been effective in treating process wastewaters from fruit, wine and sugarcane processing, but many of the associated mechanisms are poorly understood, particularly at the operational scale.

In our greenhouse studies, planted subsurface flumes with volcanic rock substrates removed approximately $80 \%$ of the inlet $\mathrm{BOD}_{5}$ and $\mathrm{COD}$ loading from molasses process wastewater, approximately 1,200 $\mathrm{mg} \mathrm{COD} / 1$ after about 3 weeks of plant growth. This ultimate removal rate was similar to the steady rate achieved in these same flumes later. The planted flumes outperformed the unplanted flumes by roughly $30 \%$ in terms of COD removal. The steady

\section{Plants can play a significant role in treating process wastewater from wineries.}

increase in $\mathrm{BOD}_{5}$-to- $\mathrm{COD}$ ratio in the effluent of planted versus unplanted flumes suggests that the plant-biofilm system was better able to degrade morerecalcitrant compounds in process wastewater.

In the winery studies, operational conditions resulted in overloading and underloading of the constructed wetlands even though HRTs were

\section{References}

González-Farias FA, Hernández-Garza MR, DíazGonzález G. 2006. Organic carbon and pesticide pollution in a tropical coastal lagoon-estuarine system in Northwest Mexico. Int J Env Pollut 26(1-3):234-53. Grismer ME. 2005. Simulation evaluation of the effects of non-uniform flow and degradation parameter uncertainty on subsurface flow constructed wetland performance. Water Env Res 77(7):3047-53.

Grismer ME, Carr MA, Shepherd HL. 1999. Literature review: Fermentation industry. Water Env Res 71(4):805-11.

Grismer ME, Carr MA, Shepherd HL. 2000. Literature review: Fermentation industry. Water Env Res 72(4):CD-ROM.

Grismer ME, Carr MA, Shepherd HL. 2003. Evaluation of constructed wetland treatment performance for winery wastewater. Water Env Res 75(5):412-21.

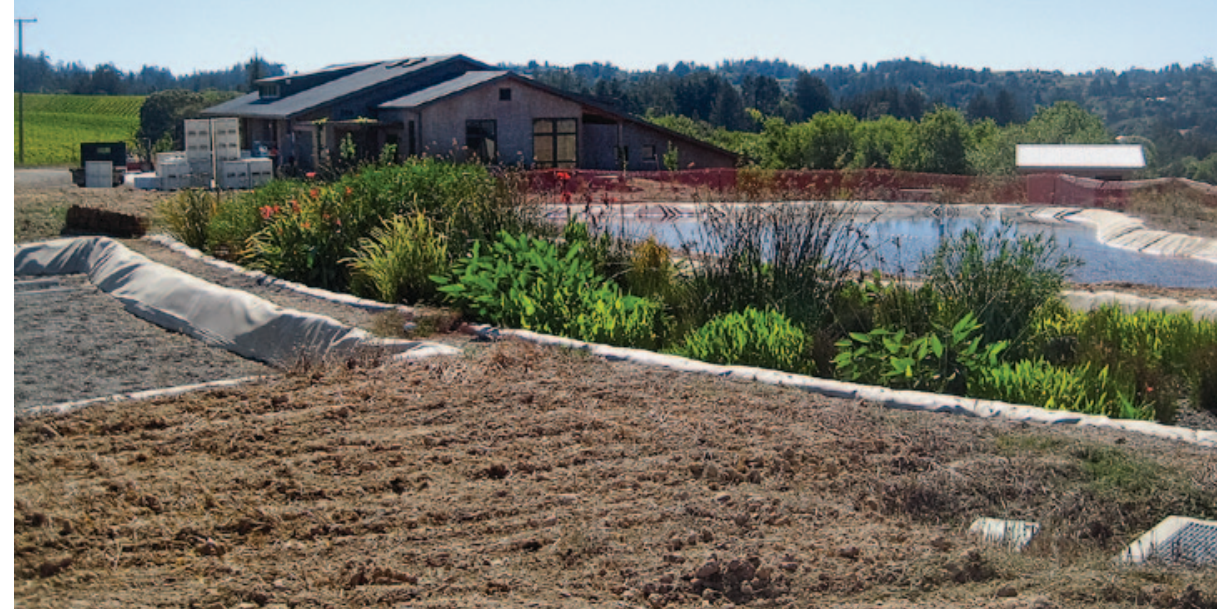

Natural treatment systems are effective in reducing organic-matter levels in wastewater, and even more so when they incorporate plants. At Lemon Winery in Sebastopol, constructed wetlands include a planted bed (center) and an unplanted pond (middle right).

designed to be the same. Average organic loadings spanned roughly 5,000 to $75,000 \mathrm{mg}$ COD/1 at HRTs of roughly 20 to 6 days, respectively. While totalsuspended-solids concentrations at the inlets were similar at both wineries, much greater HRTs at one winery resulted in greater COD removal rates. At both wineries, the planted wetlands outperformed unplanted wetlands, with COD removal of $98 \%$ versus $95 \%$, respectively; total-suspended-solids removal of $84 \%$ versus $69 \%$, respectively; and better $\mathrm{pH}$ stabilization and less total-dissolved-solids in the planted wetlands.

The slightly greater COD removal rates at the wineries may be associated with the finer substrate material used (pea gravel versus volcanic rock), plus the pea gravel possibly had greater cation exchange, or adsorption capacities, or simply a greater surface area for biofilm development. Our laboratory is investigating this issue. Nonetheless, we expect the performance of the field constructed wetlands to improve as the plant-biofilm system is further developed. Overall, as in the greenhouse studies, the field studies underscored the importance of plants to the treatment performance of constructed wetlands for the variable, highstrength process wastewaters typical of fruit, wine, distillery and sugarcane processing.

M.E. Grismer is Professor, Departments of Biologi$\mathrm{cal}$ and Agricultural Engineering, and Hydrology, UC Davis; and H.L. Shepherd is Independent Wastewater Consultant and Wetlands Specialist, Sebastapol, Calif. We thank the Instituto de Ecología, Xalapa, Mexico; the Wallace Group, San Luis Obispo; and the participating wineries and their staffs for supporting this work.
Grismer ME, Ross CC, Valentine GE. 2002. Literature review: Food processing wastes. Water Env Res 74(4):377-84.

Grismer ME, Shepherd HL. 1998. Literature review: Fermentation industry. Water Env Res 70(4):637-42.

Grismer ME, Tausendschoen M, Shepherd HL. 2001. Subsurface flow hydraulic characteristics of a constructed wetland for treatment of winery effluent. Water Env Res 73(4):466-77.

Gunkel G, Kosmol J, Sobral M, et al. 2006. Sugar cane industry as a source of water pollution - case study on the situation in Ipojuca River, Pernambuco, Brazil. Water Air Soil Poll 180(1-4):261-9.

Kumar GS, Gupta SK, Singh G. 2007. Biodegradation of distillery spent wash in anaerobic hybrid reactor. Water Res 41(4):721-30.
Nikolaev YA, Plakunov VK. 2007. Biofilm - "city of microbes" or an analogue of multicellular organisms? Microbiology 76(2):125-38.

Olguín EJ, Sánchez-Galván G, González-Portela RE, López-Vela M. 2008. Constructed wetland mesocosms for the treatment of diluted sugarcane molasses stillage from ethanol production using Pontederia sagittata. Water Res 42:3659-66.

Shepherd HL, Grismer ME, Tchobanoglous G. 2001. Treatment of high-strength winery wastewater using a subsurface flow constructed wetland. Water Env Res 73(4):394-403.

Shepherd HL, Tchobanoglous G, Grismer ME. 2001. Time-dependent retardation model for COD removal in a subsurface flow constructed wetland for winery wastewater treatment. Water Env Res 73(5):567-606. 